Arab World English Journal (AWEJ) $2^{\text {nd }}$ Special Issue on Covid 19 Challenges January 2022 DOI: https://dx.doi.org/10.24093/awej/covid2.31

Pp.466 - 478

\title{
Interaction in E-Learning Setting through Teaching English as Foreign Language by Native-English Teachers: E-Classroom Discourse
}

\author{
Eissa. Al Khotaba \\ Department of Languages and Translation \\ Faculty of Education and Arts, The University of Tabuk, \\ Tabuk, Saudi Arabia \\ E-mail: alkhotabaeissa@yahoo.com
}

Received: $11 / 3 / 2021$

Accepted: 1/12/2022

Published:1/24/2022

\begin{abstract}
This survey investigated the interaction of e-learning settings through teaching English as a foreign language by native-English teachers. It examined the instructional virtual environment in teaching EFL at the University of Tabuk in Saudi Arabia during the COVID-19 crisis during the academic year 2019/2020. Sample consisted of 20 informants. Participants were selected randomly divided into two groups (experimental 10 and control 10). Experimental group used media tools such as blackboard, zoom, interactive board, the control group used the conventional method. Pre-and post-questionnaires were distributed to both groups after completing teaching units. Results showed that there are statistically significant differences at level $(0,05)$ for the means of achievement test for both groups in favor of the experimental group through the interactive board. The findings revealed that there are statistically significant differences at level $(0,05)$ in developing attitudes of teachers towards linguistic subjects due to the use of the interactive board. The research recommends that media; blackboard, zoom, and the interactive board should be activated in teaching all subjects not only the time of crisis but also in normal times since it has a positive effect on the achievement of teachers and increases their attitudes towards teaching EFL any time any place.
\end{abstract}

Keywords: attitudes, blackboard, discourse analysis, e-learning discourse, English language teaching, interactive board, multi-media, zoom

Cite as: Al Khotaba, E. (2022). Interaction in E-Learning Setting through Teaching English as Foreign Language by Native-English Teachers: E-Classroom Discourse Arab World English Journal (AWEJ) $2^{\text {nd }}$ Special Issue on Covid 19 Challenges (2) $466-478$.

DOI: https://dx.doi.org/10.24093/awej/covid2.31 
Arab World English Journal (AWEJ) 2nd Special Issue on Covid 19 Challenges January 2022

\section{Introduction}

Current development in the field of communication provided more attention to the use of information technology (Adnyani et al., 2020). Traditional teaching techniques that have the basis of teaching English language at many academic institutions worldwide have not given teachers and learners adequate opportunity to contribute and achieve knowledge. Techniques that relied on route learning commonly emphasized the theoretical notion of education rather than the applied part. This is not enough in learning and teaching languages that usually depend on both the theoretical and applied aspects (King, 2017). Prospectus has not developed to be the only source of knowledge and offers learners with information and skills that they need to attain critical thinking skills and be innovative (Urizar, Andi \& Tuti, 2018).

According to Gibeault (2018), current education systems turned to be reliant on a computer and are the latest development in the human sciences field. Adopting only computers as a teaching technique is not satisfactory, it should be escorted with contemporary teaching techniques and computerized programs that suit all the diverse academic levels. The necessity for advanced hi-tech programs that encounter the difficulties of all disciplines in language and linguistics, in particular, has become essential. This is to make the educational process more collaborative and positive to affect not only learners' academic achievement but also faculty's performance to inspire them to be academic-oriented (Tamilarasan, Anitha \& Saravanan, 2019). There is no doubt that all contemporary databases that depend on multimedia are the origins of the teaching process. Educationists should give enough consideration to these aspects in the academic institutes because contemporary teaching approaches are learners' oriented and help learners to be communicative. The use of techniques allows learners to have great involvement in the process of obtaining knowledge and developing creative thinking skills (Sydorenko, Daurio, \& Thorne, 2018).

Rustam and Mengke (2020) state that the emphasis on information technology whether in lower or higher education levels has become a concern of every learner due to learning process connection. The importance of information technology is perceived in advancing the educational level as well as evolving the learners' critical thinking skills and creativity. One of the most important techniques used is "blackboard" technology. Many practical features make such technology effective as they essentially rely on many contemporary programs that languages learners need. The educational field witnessed countless developments in language acquisition techniques that urge the whole world to be well-prepared to face global challenges in the field of technology nowadays (Kelly-Irving et.al., 2017). Tang (2019) states that the primary objective of teaching is growth and development. Learning is should be improved to provide learners with enough training programs on applying technology. Various countries worldwide have called for strengthening efforts to connect all educational institutions through internet and websites technology.

For example, regions such as USA and China witnessed an extreme development of technology at both universities and schools levels (Montanero \& Marques, 2018). Alenezi and Shahi (2015) argued that numerous international initiatives to reassure these 
Arab World English Journal (AWEJ) 2nd Special Issue on Covid 19 Challenges January 2022

countries to incorporate computers in the academic sector. An example is the United Nations Development Program which has been introduced to the Arab countries by bringing about progress in their computer-mediated learning systems to attain development. The Egyptian minister of education highlighted that computer-mediated programs should be applied to meet both global and local needs to make education more innovative and contemporary (Al-Drees, Khalil, Meo, \& Abdulghani, 2015). E-learning and computer-mediated educational programs have become one of the most significant fields of debate in academia (Tang, 2019). Operative definitions and the educational policy of computer-mediated programs differ from one place to another. Adopting computers will not just be giving new technology but will provide a contemporary mode of learning that necessitates exceptional criteria such as the preparation and training of the academic staff and supporting them to be aware of computer-based programs concepts and what potential benefits can be attained (Alenezi \& Shahi, 2015).

\section{Literature Review}

COVID-19 created by novel human coronavirus in 2019, serious acute respirational syndrome coronavirus 2 (SARS-CoV2) originated in Wuhan city in China in 2019. World Health Organization reported infection of 414,179 and 18,440 death cases of COVID-19. The quick extent of disease, an increasing number of death cases, and the necessity for salutary and vaccination, motivated many administrations and health advisors to use firm regulations to combat the pandemic. Epidemic included public lockdown, academic institutions, and non-essential congregations. Data proposes that nations that used decisive and early interferences might have aided in decreasing the spread of syndrome. Public distancing has been an important procedure to alleviate the spread of COVID-19 that is aimed at reducing the probability of contact between infected persons and others who are not infected (Yezli \& Khan., 2020).

Similarly, academic institutions in Saudi Arabia have taken necessary actions to restrict the spread of COVID-19 employing social distancing at its various educational levels (schools, colleges, and universities). Applying firm measures for social distancing is thought-provoking, particularly in colleges and universities in Saudi Arabia (KSA, hereafter) because of its level of urbanization, social structures, religious norms, and annual hosting of high visibility international religious mass gatherings and pilgrims. Suadi Arabia began to acquaint crucial social distancing actions sometimes before the first case of COVID-19 was reported in the country stretching from cancelations of academic activities and practices. Closing of educational establishments suspended all non-essential crowds to force partial curfew.

Actions were applied despite their educational, socio-economic, political, and religious encounters for the sake of public health. Importance of these procedures on the extensive curve of KSA and international reaction against COVID-19 reside to be experienced (Yezli \& Khan, 2020). Due to a cumulative number of COVID-19 cases in Saudi Arabia, the government imposed restricted measures and suspended local public services delivery in an intense fortitude to eradicate the spread of disease. This affected the quality of education in both private and public sectors locally as well as internationally to switch to e-learning. Martuk, et al. (2021) state that "the spread of COVID-19 poses a 
Arab World English Journal (AWEJ) 2nd Special Issue on Covid 19 Challenges January 2022

threat to humanity, as this pandemic has forced many global activities and educational activities, despite the challenges facing this sudden transformation" (p.1).

Aboagye et al. (2020) investigated challenges that learners encounter when dealing with e-learning during the outbreak of COVID-19. Findings showed that a blended approach that includes traditional and e-teaching should be accessible for learners. Eclassroom discourse refers to the teacher's control over discussion and interaction. It has been viewed through the contribution of both teachers and students through a means of turn-taking (Tang, 2019). Controlling classroom discourse restricts active interaction. Learners may only learn language by getting involved in communication established when socializing. Used language develops to be an entity of learners' cognitive resources making teaching effective through providing new knowledge to learners. Learning should focus on the assimilation process, establishing active cognitive sets, applying accommodation, and advanced organizers to help retain knowledge for a longer time and be repossessed sooner; moreover, learners' cognitive skill is built.

Teachers were inclined to restrict speaking prospects for learners by posing questions that achieve educational objectives but avoid interlocutors from the emerging discussion. They, also, disrupt pragmatic interactions of conversation (Rustam \& Mengke, 2020). Research shows that teachers' restricted e-classroom discourse initiated observations that raise complicated questions to address because of the limited period provided for interaction. Teachers should recognize that because teacher-fronted activities control e-classroom interaction, they have to backup teaching by appropriate use of interactions (Montanero \& Marques, 2018). Research indicates that teacher-initiated problems may advance collaboration, increase comprehension and support the second language/foreign language acquisition. It shows that teachers who intend to include students in meaningful interface support help their cognitive development. The sociocultural theory proposes that cultural and cognitive development occurs because of social interaction between learners and a more experienced instructor or a classmate by structuring a system of scaffolding, i.e. by shortening tasks, serving to discover solutions, taking learner's responsiveness to a significant component of language, transferring meaning (Adnyani, et al., 2020). Knowledge is improved when learners communicate meaning with other teachers or classmates as assumed by the Interaction Hypothesis. Learners are given support to take their attention to changes between their interlanguage and first language practices. They might observe where improvement is required. Interaction is important as a facilitator in the process of teaching a foreign language pointing out that language learning development may be achieved through language generation and the use of linguistic skills (Urizar, et al., 2018).

In regard, much research has been conducted to examine the prerequisites for modifying the teaching syllabus to meet learners' technological requirements. But there is no detailed connection between scholars and educationists over the nature and extent of the variations that should be completed. Introducing changes to the existing teaching and learning materials is realized by several parents and scholars as a novel idea to encounter challenges of new technology (Aljawarneh, 2020). Making changes in the teaching materials through computers in education is the only technique to handle exchanging 
information and improving in the field. Implementing computers in learning is one of the modern patterns that result in the progress and development of the learner not only in the field of human sciences but even in pure sciences (Kelly et.al., 2017). Past literature found out that computer-based education is far better and more developed compared with conventional teaching methods (Gibeault, 2018). The rapid development of network provided different definitions to the term e-Learning such as Web-Based Learning: WBL, Web-Based Instruction-WBI, Web-Based Training-WBT, Internet-Based Training-IBT, Distributed Learning-DL, Advanced Distributed Learning- ADL, On-line Learning-OL, Mobile or m-Learning, Nomadic Learning, Remote Learning, Off-site learning, and alearning: anytime, anyplace, anywhere learning (Sauro \& Sundmark, 2019).

Montanero and Marques (2018) argue that e-Learning comprises the following terms: distance learning, online learning, web-enabled learning, distributed learning. Words such as electronic learning are used at present to represent effective integration of a range of support to traditional learning that can take place in lecture halls, from home, and at the workplace, not limited to one place. The most common feature amongst all is a learning technique that uses the mechanisms of modern communication, computer networks, multiple modes of voice and pictures, drawings, electronic libraries, and Internet portals, either remote or in the classroom (Yamazaki, 2018).

Communication technology such as television, videotape, computers, e-mail, and mail depends on the Internet /World Wide Web. Technology can either be formal, informal, or be used for professional development via any electronic methods such as the internet, CD-Rom, videotape, and DVD. It enables learners to learn whenever and wherever they want and provides them with flexible access to materials at learners' convenience'. This seems valid to explore the potential advantages of technology in detail (Ramezanali, 2019). E-learning can provide the learners with the ability to read texts, investigate pictures, listen to explanations and even interact with the teachers. Research findings stated that e-learning can help learners memorize $10 \%$ of the information prepared within a classroom and $20 \%$ to $40 \%$ of what they see or listen (Shadiev, Hwang \& Liu, 2019).

To conclude, the emergence of information technology and computer-based learning has changed the role of language teachers in the classroom. Focus has changed to allow learners to be the core of the education process (Gautam, 2020). It has shifted to make language learners self-independent and have the skill to use multimedia and information technology in learning the English process. Information technology (IT, hereafter) provides language learners with the required skills for getting knowledge. IT has developed to be significant to implement modern teaching techniques so that learners can reach the goals of the academic process to update the traditional teaching techniques used by the academic institutions instead of focusing on learners' achievement.

Implementing modern multimedia, techniques, and the availability of e-discourse settings should help learners develop a natural process. So, improvising the quality of learning by implementing multimedia and modern techniques such as Blackboard (Ismail \& Saleh, 2018). Most Saudi EFL learners face many problems when they try to use 
Arab World English Journal (AWEJ) 2nd Special Issue on Covid 19 Challenges January 2022

multimedia such as the blackboard. They do not have the skills to use tools such as "blackboard" effectively in EFL classes with native English teachers (Al-Drees et al., 2015).

\section{Research Objectives}

This research intends to achieve the following objectives:

i. To examine the influence of e-learning environments on the efficacy of native-English teachers in teaching English as a foreign language.

ii. To find out whether there are any impacts due to implementing e-learning settings on developing native-English teachers' attitudes towards learning the English language.

\section{Research Questions}

This study addresses the following research questions:

i. What is the influence of e-learning environments on the efficacy of nativeEnglish teachers in teaching English as a foreign language?

ii. Are there any impacts due to implementing e-learning environments on developing native- English teachers' attitudes towards learning the English language?

\section{Methodology}

The corpus included 20 native-English teachers (males) from the Institute of Languages at the University of Tabuk in Saudi Arabia.

\section{Sampling}

The researcher used random sampling procedures in selecting informants. Participants were distributed randomly over the control and experimental groups. The researcher was an Associate professor and possessed good information about native-English teachers' backgrounds. The selection of the Institute of Languages was motivated by the fact that teachers have used blackboard techniques during their teaching classes and others have not. Native-English teachers selected are native teachers (British and American). They are similar in gender and age, ranging from 32-58 years. The control group used the conventional method and the experimental group used an e-learning setting (blackboard, zoom, and interactive board) to achieve reliability, validity, and efficiency of blackboards teaching the English Language at the University of Tabuk.

\section{Research Instruments}

The researcher used two research methods including:

\section{An Active Inspire}

Percentages were fixed on teaching English language to advanced learners considering teachers' achievement. The test involved 25 multiple-choice articles and paragraphs 
validated by a panel of experts specialized in e-learning. Changes were made to minimize test items to 20 paragraphs. The objective of the test was to measure the difference in achievement tests for both experimental and control groups in the English language curriculum at the Institute of Languages.

\section{A Questionnaire Survey}

Then, the researcher designed a questionnaire including 12 articles distributed into four headings. The researcher followed certain procedures to carry out efficiency tests and statistical analyses for eliciting responses from participants. In correspondence with the efficiency test, the researcher conducted a questionnaire survey: the questionnaire was distributed over two groups to find similarities and differences. Then, a post-questionnaire was distributed to participants after experimenting with the e-learning setting and conventional method. The researcher conducted a statistical analyses program (SPSS, v.24).

\section{Discussion}

Findings of the first hypothesis showed that there are no statistically individual differences at $(0$, 05) level due to e-learning setting, particularly Blackboard. Findings of the analysis of independent t-test are discussed as follows in Table One:

Table 1. Findings of the T-test differences between the control and experimental groups

\begin{tabular}{|c|c|c|c|c|c|c|c|c|}
\hline Groups & Mean & $\begin{array}{l}\text { Standard } \\
\text { Deviation }\end{array}$ & $\begin{array}{l}\text { The } \\
\text { bety } \\
\text { the }\end{array}$ & $\begin{array}{l}\text { Difference } \\
\text { en } \\
\text { vo Groups }\end{array}$ & $\begin{array}{l}\text { T. Test } \\
\text { Value }\end{array}$ & $\begin{array}{l}\text { T. Test } \\
\text { Periodic } \\
\text { Value }\end{array}$ & Temperature & Level \\
\hline Control & 14.1 & 5.18 & $\begin{array}{l}\mathrm{Me} \\
\text { an }\end{array}$ & $\begin{array}{l}\text { Standard } \\
\text { Deviation }\end{array}$ & \multirow[t]{2}{*}{3.08} & \multirow[t]{2}{*}{2.03} & \multirow[t]{2}{*}{25} & \multirow[t]{2}{*}{0.000} \\
\hline Experimental & 18.1 & 1.81 & 4 & 3.37 & & & & \\
\hline
\end{tabular}

Table one depicts that the results of tests indicated that the means for the experimental group is 18.1 with a standard deviation of 1.81 and the means for the control group was 14.1 with a standard deviation of 5.18. Findings showed that statistical conflict for the two means of the experimental and control group is four and the difference for standard deviations of the two groups is 3.37 at level (0.05). T-test value was 3.08 at level $(0.00)$, and the t-test periodic value was 2.03. The result of the $t$-test is in favor of the experimental group.

The researcher discards the null-hypothesis category and uses a substitute with a statistical difference at 0.05 inefficiency of native- English teachers. To test the second hypothesis stating that there are no statistical differences in developing attitudes of nativeEnglish teachers at the Institute of Languages at 0.05 , the researcher concluded the means and standard deviations for the items of the questionnaire as depicted in Tables one and two in the next section. Findings show that the means value for responses of the questionnaire concerning the experimental group is 1.6-1 and 2.61-1.38 for the control group with a standard deviation value of $0.94-0.51$. 
Arab World English Journal (AWEJ) 2nd Special Issue on Covid 19 Challenges January 2022

Experimental group standard deviations varied between $0.69-0$. Results indicated that there is a statistical difference and effect for use of e-learning settings (blackboard, zoom, and interactive board) on developing the attitudes of teachers in teaching the English language. T-test independent findings showed that there is an effect because the t-test value was 3.08 at level 0.00. This confirms rejection of null hypothesis and accepts substitute "there is an effect with a statistical difference in developing the attitudes of native-English teachers to blackboard, zoom and interactive board in teaching English as a foreign language.

\section{Experimental Group}

Table 2. Attitude toward Adopting e-learning tools in teaching English as a Foreign Language for the experimental group

\begin{tabular}{|c|c|c|c|c|}
\hline & $\begin{array}{l}\text { Standard } \\
\text { Deviation }\end{array}$ & Mean & Item & Subscale Item \\
\hline \multicolumn{4}{|c|}{ Like English as a Foreign Language Lessons } & \multirow{4}{*}{$\begin{array}{l}\text { Section } \\
1\end{array}$} \\
\hline & 0.69 & 1.61 & $\begin{array}{l}\text { I like teaching the English language using } \\
\text { Blackboard, ZOOM, or Interactive Board } \\
\text { during COVID-19. }\end{array}$ & \\
\hline & 0.47 & 1.11 & $\begin{array}{l}\text { English language lessons are engaging using } \\
\text { Blackboard, ZOOM, or Interactive Board } \\
\text { during COVID-19. }\end{array}$ & \\
\hline & 0 & 1 & The English language is my favorite subject. & \\
\hline \multicolumn{4}{|c|}{ Like English as a Foreign Language Work } & \multirow[b]{4}{*}{$\begin{array}{l}\text { Section } \\
2\end{array}$} \\
\hline & 0.47 & 1.11 & $\begin{array}{l}\text { I like to do English language classes using } \\
\text { Blackboard, ZOOM, or Interactive Board. }\end{array}$ & \\
\hline & 0.51 & 1.16 & $\begin{array}{l}\text { When I use Blackboard, ZOOM, or Interactive } \\
\text { Board during COVID-19 in teaching English } \\
\text { as a Foreign Language, I feel I am doing } \\
\text { Something important. }\end{array}$ & \\
\hline & 0.23 & 1.05 & $\begin{array}{l}\text { Teaching English as a Foreign Language at IL } \\
\text { is fun. }\end{array}$ & \\
\hline \multicolumn{4}{|c|}{ Evaluative Beliefs about IL English as a Foreign Language. } & \multirow[b]{4}{*}{$\begin{array}{l}\text { Section } \\
3\end{array}$} \\
\hline & 0.46 & 1.27 & $\begin{array}{l}\text { English as a Foreign Language is useful for } \\
\text { solving communication problems worldwide. }\end{array}$ & \\
\hline & 0.23 & 1.05 & $\begin{array}{l}\text { People must learn English as a Foreign } \\
\text { Language because it affects their lives. }\end{array}$ & \\
\hline & 0 & 1 & $\begin{array}{l}\text { English as a Foreign Language is one of the } \\
\text { most important subjects to learn. }\end{array}$ & \\
\hline \multicolumn{4}{|c|}{ Behavioral Tendencies to Teach English as a Foreign Language. } & \multirow[b]{4}{*}{$\begin{array}{l}\text { Section } \\
4\end{array}$} \\
\hline & 0.68 & 1.66 & $\begin{array}{l}\text { I am willing to spend more time teaching } \\
\text { English as foreign language books. }\end{array}$ & \\
\hline & 0.51 & 1.66 & $\begin{array}{l}\text { I like trying to solve new linguistic-based } \\
\text { problems in English. }\end{array}$ & \\
\hline & 0.57 & 1.27 & $\begin{array}{l}\text { I would teach students how to do a research } \\
\text { project in the English Language. }\end{array}$ & \\
\hline
\end{tabular}


Arab World English Journal (AWEJ) 2nd Special Issue on Covid 19 Challenges January 2022

Interaction in E-Learning Setting through Teaching English

Al Khotaba

\section{Control Group}

Table 3. Attitude toward English as Foreign Language lessons scale for the control group

\begin{tabular}{|c|c|c|c|c|}
\hline & $\begin{array}{l}\text { Standard } \\
\text { Deviation }\end{array}$ & Mean & Item & Subscale Item \\
\hline \multicolumn{4}{|c|}{ Like English as a Foreign Language Lessons } & \multirow{4}{*}{$\begin{array}{l}\text { Section } \\
1\end{array}$} \\
\hline & 0.70 & 2.5 & $\begin{array}{l}\text { I like teaching the English language using } \\
\text { Blackboard, ZOOM, or Interactive Board during } \\
\text { COVID-19. }\end{array}$ & \\
\hline & 0.94 & 1.78 & $\begin{array}{l}\text { English language lessons are engaging using } \\
\text { Blackboard, ZOOM, or Interactive Board during } \\
\text { COVID-19. }\end{array}$ & \\
\hline & 0.80 & 2.22 & The English language is my favorite subject. & \\
\hline \multicolumn{4}{|c|}{ Like English as a Foreign Language Work } & \multirow{4}{*}{$\begin{array}{l}\text { Section } \\
2\end{array}$} \\
\hline & 0.51 & 1.16 & $\begin{array}{l}\text { I like to do English language classes using } \\
\text { Blackboard. }\end{array}$ & \\
\hline & 0.77 & 1.38 & $\begin{array}{l}\text { When I use Blackboard, ZOOM, or Interactive } \\
\text { Board during COVID-19 in teaching English as a } \\
\text { Foreign Language, I feel I am doing Something } \\
\text { important. }\end{array}$ & \\
\hline & 0.78 & 1.44 & $\begin{array}{l}\text { Teaching English as a Foreign Language at the } \\
\text { IL is fun. }\end{array}$ & \\
\hline \multicolumn{4}{|c|}{ Evaluative Beliefs about IL English as a Foreign Language. } & \multirow{4}{*}{$\begin{array}{l}\text { Section } \\
3\end{array}$} \\
\hline & 0.75 & 2.11 & $\begin{array}{l}\text { English as a Foreign Language is useful for } \\
\text { solving communication problems worldwide. }\end{array}$ & \\
\hline & 0.84 & 1.61 & $\begin{array}{l}\text { People must learn English as a Foreign Language } \\
\text { because it affects their lives. }\end{array}$ & \\
\hline & 0.90 & 1.88 & $\begin{array}{l}\text { English as a Foreign Language is one of the most } \\
\text { important subjects to learn. }\end{array}$ & \\
\hline \multicolumn{4}{|c|}{ Behavioral Tendencies to Teach English as a Foreign Language. } & \multirow{4}{*}{$\begin{array}{l}\text { Section } \\
4\end{array}$} \\
\hline & 0.60 & 2.61 & $\begin{array}{l}\text { I am willing to spend more time teaching English } \\
\text { as foreign language books. }\end{array}$ & \\
\hline & 0.93 & 1.94 & $\begin{array}{l}\text { I like trying to solve new linguistic-based } \\
\text { problems in English. }\end{array}$ & \\
\hline & 0.90 & 1.66 & $\begin{array}{l}\text { I would teach students how to do a research } \\
\text { project in the English Language. }\end{array}$ & \\
\hline
\end{tabular}

Findings of the first research hypothesis showed that there are statistical differences in efficiency tests of native-English teachers in favor of the experimental group adopting Blackboard, ZOOM, or Interactive Board for teaching English during the COVID-19 crisis. Use of e-learning developed the efficiency of teachers showing greater efficiency compared to the conventional method.

Results showed that teachers were less tense and productive in their tests when adopting Blackboard, ZOOM, or Interactive Board during COVID-19. English as a foreign language subject is a colorful, pictorial subject, and helpful. It also helps them consume less time, effort, and space via video motions.

Findings indicate that there is an effect of e-learning setting on teachers' attitudes towards teaching English as a foreign language. It also showed there are differences in responses of teachers to questionnaires in favor of the experimental group. The researcher 
concluded these differences by comparing the means and standard deviations related to the articles for both control and experimental groups as confirmed by findings of an independent t-test. This may relate to the advantages of technology and its effect on attracting learners to engage in the learning process due to the audio-visual effects of e teaching materials. Results recommend that further future research be conducted in this field.

The significance of e-classroom interaction as simplifying aspect in teaching EFL as reported by teachers during COVID-19. It shows that language skills' development may be achieved by language generation in an actual e-discourse setting that helps students to use their linguistic skills to be developed and understood.

\section{Results}

Findings of the survey as discussed from native teachers' stances assume that e-classroom learning (Blackboard, ZOOM, or Interactive Board) is adopted as a scientific strategy acquired through multimedia platforms. They showed that e-discourse is helpful and that it assists them to develop their academic records and achievement. Teachers asserted that the adoption of e-discourse is complicated and that the low internet connectivity problem. Results indicated that there are restrictions to e-classroom despite including many disadvantages such as reducing the capacity for teachers and increasing weight on learners. Teachers believe that e-learning is useful and facilitates improving learners' high-tech skills as one of the most practical components.

Conclusions indicate teachers' agreement on the importance, accessibility, and practicality of e-classroom /learning discourse despite the appearance of barriers to overview and expenses of adopting technology practices. The result presented that teachers' agreed that computer-mediated learning has difficulties and that the most common shortcoming is that, compared to conventional teaching and learning, it necessitates financial sources. There are statistically significant differences at level $(0,05)$ in developing attitudes of native-Engish teachers towards linguistic subjects due to Blackboard, ZOOM, or Interactive Board, particularly at a time of crisis or pandemics.

\section{Pedagogical Implications}

Each e-learning approach adopts one of the generally recognized learning theories, i.e., behaviorism, cognitivism, or constructivism (Adnyani et al. 2020). Each informative approach possesses a more or less solid weight on the aspects that affect the learning development and the self-evaluation of the learner's individualities. Hence, grounded on what has been realized based on the views of the teachers and learners confirming that the positive characteristics of the learner, specifically, motivation should be examined. Also, it is essential, as an applicable instructive stage, to select an e-learning approach that outfits the characteristics of learners and the e-classroom setting they are existing in currently.

\section{Conclusion}

This survey aims to investigate interaction in an e-discourse setting by teaching English as a foreign language by native-English teachers at the Institute of Languages at the University of Tabuk in Saudi Arabia during the COVID-19 crisis from a communication discourse perspective. Sample comprised native-English teachers implementing a 
descriptive-analytical approach ( SPSS, v.24) to analyze data elicited from the questionnaires and tests. Teaching EFL adopting an electronic setting still offers several benefits, decreasing costs and affords. It was also a positive substitute for different nativeteachers on teaching in academic organizations by the extent of the Covid-19 pandemics, despite encountering several concerns and difficulties. By examining the effects, it is found that these are positive results to highpoint the problems, challenges, and advantages of adopting the e-classroom learning setting at the tertiary education level. Concerns such as practical and monetary funding, teaching, better-quality working settings, technological infrastructures, services, exclusive rights securities, and professional development are constantly significant in the adoption /acceptance of e-Classroom in governmental universities such as the University of Tabuk.

To conclude, native-English teachers believe that e-classroom has a significant role in students' learning and academic achievement. It decreases and escalates the workload on faculty and learners. Key difficulty to e-classroom is the Internet disconnectivity and backup throughout the campus (IL- the University of Tabuk) during the pandemic or COVID-19 crisis due to the heavy workload. Faculty accept e-classroom that is convenient in developing learners' high-tech skills. One can propose that it is significant to highpoint several of the references that can have a constructive effect on adopting or accepting eclassroom. The IL at the University of Tabuk or any other public academic institution should offer high-quality internet services both to teachers and learners with an adequate supply of computer devices to adopt e-classroom.

A contemporary e-library and digital e-classrooms with all educational practices and implements required are also indispensable to adopt e-classroom as an alternative to site classroom. Holding online teaching, workshops, classes, and sessions frequently is significant, for teachers, in specific, to back up the use and adoption of e-classroom, besides to persistent attention to information technology structure and regular repairs of edevices and additional tools. Further, the contribution and significance of concentrating on several effects associated with the features of the learner, such as the individualities of the learner's contextual awareness and how to encourage the learners as one of the academic effects.

\begin{abstract}
About the Author
Dr. Eissa Al Khotaba is an Associate Professor of Discourse Analysis at the Faculty of Education and Arts, Dept. of Languages and Translation, University of Tabuk, KSA. He is the Head of the Research Unit at the Institute of Languages. His primary focus is on linguistics, discourse, translation, and English language teaching.
\end{abstract}

\title{
References
}

Adnyani, Luh Diah Surya and Mahayanti, Surya \& Suprianti, G. A. P. (2020). Pow Toon-Based Video Media for Teaching English for Young Learners: An Example of Design and Development Research. Proceedings of the 3rd International Conference on Innovative Research across Disciplines (ICIRAD 2019), 221-226. 
Arab World English Journal (AWEJ) 2nd Special Issue on Covid 19 Challenges January 2022

Al-Drees, A., Khalil, M. S., Meo, S. A., \& Abdulghani, H. M. (2015). Utilization of blackboard among undergraduate medical students: Where we are from the reality? Journal of Taibah University Medical Sciences, 10(1), 16-20.

Alenezi, A. M., \& Shahi, K. K. (2015). Interactive e-learning through Second Life with Blackboard Technology. Procedia - Social and Behavioral Sciences, 176, 891-897. DOI: https://doi.org/10.1016/j.sbspro.2015.01.555.

Aljawarneh, S. A. (2020). Reviewing and exploring innovative ubiquitous learning tools in higher education. Journal of Computing in Higher Education, 32, 57-73. https://doi.org/10.1007/ s12528-019-09207-0.

Chen, J.J (2016). Enhancing Student Engagement and Interaction in E-Learning Environments through Learning Analytics and Wearable Sensing, (Unpublished Doctoral dissertation) Hong Kong Baptist University, Hong Kong, China. Available online: http://repository.hkbu.edu.hk/etd_oa/287.

Dennen, V.P., Branch, R.C. (2019). Considerations for Designing Instructional Virtual Environments. Available online: https://eric.ed.gov/?id=ED391489.

Gautam, P. (2020). Advantages and disadvantages of online learning. In E-Learning Industry. Gibeault, M. J. (2018). Organization of Materials and Accessing the Library in Blackboard: A Learner-centered Usability Study. The Journal of Academic Librarianship, 44, 190195. Doi: https://doi.org/10.1016/j.acalib.2018.02.008

Kelly-Irving, M., et al., (2017). Vignettes as a tool for research and teaching in life course studies: Interdisciplinary approaches. Advances in Life Course Research, 32, 35-41. Doi: https://doi.org/10.1016/j.alcr.2016.09.001.

King, J. (2017). Reimagining the Role of Technology in Education: 2017 National Education Technology Plan Update. U.S.: US Department of Education. Resource URLhttps://tech.ed.gov/files/2017/01/NETP17.pdf.

Martuk, A.M., Elberkawi, E.K., Aljawarneh, S. et al. The COVID-19 pandemic and E-learning: challenges and opportunities from the perspective of students and instructors. J Comput High Educ (2021). https://doi.org/10.1007/s12528-021-09274-2.

Montanero, M., \& Marques, M.-J. (2018). "Explain it on the blackboard". An analysis of the educational interaction in mirror assessment activities. Learning, Culture, and Social Interaction, 22, 51-61. Doi: https://doi.org/10.1016/j.lcsi.2018.07.003.

Ramezanali, N., and Faez, F. (2019). Vocabulary learning and retention through multimedia glossing. Language Learning and Technology, 23(2), 105-124.

Shadiev, R., \& Yang, M. (2020). Review of Studies on Technology-Enhanced Language Learning and Teaching. Sustainability, 12, 1-22. Doi: 10.3390/su12020524.

Sauro, S. and Sundmark, B. (2019). Critically examine the use of blog-based fanfiction in the advanced language classroom. ReCALL, 31, 40-55. DOI: https://doi.org/10.1017/S0958344018000071

Shadiev, R., Hwang, W.Y., \& Liu, T.Y. (2019). A study of the use of wearable devices for healthy and enjoyable English as a foreign language learning in authentic contexts. Journal of Educational Technology \& Society, 21(4), 217-231.

Sydorenko, T., Daurio, P., and Thorne, S. L. (2018). Refining pragmatically appropriate oral communication via computer-simulated conversations. Computer Assisted Language Learning, 31(1-2), 157-180. https://doi.org/10.1080/09588221.2017.1394326. 
Arab World English Journal (AWEJ) 2nd Special Issue on Covid 19 Challenges January 2022

Tamilarasan, P., Anitha, D., \& Saravanan, K. (2019). Integrating Technology into English Language Teaching: An Analysis. International Journal of Recent Technology and Engineering, 8(1), 973-976.

Tang, X. (2019). The effects of task modality on L2 Chinese learners' pragmatic development: Computer-mediated written chat vs. face-to-face oral chat. System, 80, 48-59.

Urizar, A. S., \& Tuti. H. (2018). The Effectiveness of Use Multimedia in English Teaching at SMPN 1 Meulaboh. Proceedings of the $1^{\text {st }}$ International Conference on Social Sciences and Interdisciplinary Studies (ICSSIS 2018), 208, 47-48

Uziak, J., Oladiran, M. T., Lorencowicz, E., \& Becker, K. (2018). Students and Instructor's Perspective on the use of Blackboard Platform for Delivering an Engineering Course. The Electronic Journal of e-Learning, 16(1), 1-15. http://www.ejel.org/volume16/issue1/p1.

Yamazaki, K. (2018). Computer-assisted learning of communication (CALC): A case study of Japanese learning in a 3D virtual world. ReCALL, 30(2), 214-231. DOI: https://doi.org/10.1017/S0958344017000350

Yezli, S., \& Khan, A. (2020). COVID-19 social distancing in the Kingdom of Saudi Arabia: Bold measures in the face of political, economic, social and religious challenges. Travel Medicine and Infectious Disease. 